\title{
EDITORIAL
}

\section{In This Issue: From Communities of Solution to Joy}

\author{
Kurt C. Stange, MD, PbD, Editor \\ Ann Fam Med 2012;10:194-195. doi:10.1370/afm.1415.
}

$\mathrm{T}$ his issue features a bold proposal for community-focused approaches to improving health. While the approaches are new, they build on a blueprint from more than 40 years ago. In addition, a cluster of articles present new knowledge for the care of diverse groups of vulnerable people. Another clinical research article summarizes scientific evidence for a limited nonantibiotic treatment for sinusitis. A novel proposal and an editorial consider paying patients for "performance" reaching measurable health goals, while a study of a large scheme for paying practices for performance is shown to have no effect on reducing ethnic disparities in management of diabetes. A study of the effect of electronic health records on diabetes care improvement, a useful methodological reference for practice-based research, and an essay that reveals a path toward the joy of family medicine, round out the issue.

\section{COMMUNITIES OF SOLUTION}

In a report proposing communities of solution, a group of rising family medicine leaders, calling themselves the Folsom Group, revitalize and modernize the grand challenges from the landmark 1967 Folsom Report. ${ }^{1,2}$ This proposal for vitalizing community-centered approaches to improving health calls on the best traditions of local action, public health, and primary health care. A recent Institute of Medicine report ${ }^{3}$ recommends both federal and local efforts that will support the Community of Solution vision. And around the country and in whole systems around the world varied partners and multistakeholder groups are working together to address problems and create opportunities to improve the health of their communities. The Annals editors encourage readers to share your experiences of communities of solution and develop ideas for realizing even a portion of this expansive vision: $\log$ on to the TRACK discussion of articles at http://www. AnnFamMed.org. The Annals Journal Club ${ }^{4}$ provides questions to guide group discussion.

\section{UNDERSTANDING AND IMPROVING CARE FOR VULNERABLE PEOPLE}

A randomized clinical trial by Margolis and colleagues ${ }^{5}$ finds that home blood pressure monitoring and weekly health coaching are associated with reduced blood pressure in low-income minority patients with poorly controlled hypertension, but it finds no effect of home titration of blood pressure medications.

For older adults with low levels of physical activity, Kolt and colleagues ${ }^{6}$ assess the effect of a "green prescription"-a recommendation for physical activity with pedometer monitoring. In a clinical trial of 330 adults older than 65 years, they find that a green prescription increases leisure walking without an effect on overall activity levels.

In a qualitative study of women in Lebanon, Usta et al find that even in a conservative society, most women want their clinicians to assess the possibility of domestic violence, and they want their health care system to address what is uncovered. ${ }^{7}$

Pay-for-performance schemes have been touted as a route to reducing health care inequalities. In a study in the UK's Quality and Outcomes Framework (QOF), Alshamsan et al find that introduction of QOF had no effect on health care inequalities in 29 general practices. ${ }^{8}$

\section{CONTROVERSIAL TOPICS}

As evidence and clinical policy recommendations move away from antibiotic use for acute sinusitis, ${ }^{9}$ a helpful meta-analysis by Hayward and colleagues finds a small therapeutic benefit from intranasal corticosteroids. ${ }^{10}$ The effect is not apparent until 2 to 3 weeks, however, and most studies also included antibiotics, making it difficult to tease out the independent effect of steroids. An editorialist ${ }^{11}$ is skeptical about anything but limited use of intranasal steroids for selected patients with sinusitis.

An essay by Wu proposes paying patients for per- 
formance by rewarding them for achieving evidencebased health goals. ${ }^{12}$ An editorial by Christiansen ${ }^{13}$ supports the concept of reinforcing positive behavior but argues that the literature on incentives does not yet justify such a proposal.

\section{METHODS, THE ELECTRONIC HEALTH RECORD, AND JOY}

In an interesting spin on the term "meaningful use" of electronic health records, Crosson et al find no association of electronic medical record use and measures of the quality of diabetes care over a 3 -year period. ${ }^{14}$

Thompson and colleagues provide information on clustering of data from more than 5,000 patients in 61 practices in 8 practice-based research networks across the United States. ${ }^{15}$ The details of these intraclass correlation coefficients across multiple patient characteristics, practices, and networks will be of use to practice-based researchers in planning studies to assure adequate statistical power.

Finally, an essay by Ventres shares the personal joy of being a family physician and suggests 6 themes that continue to rejuvenate his practice. ${ }^{16}$

We welcome your reflections on all articles at http://www.AnnFamMed.org.

\section{References}

1. Folsom MB. American Public Health Association and National Health Council. Health is a Community Affair. Report of the National Commission on Community Health Services. Boston, MA: Harvard University Press; 1967

2. The Folsom Group. Communities of solution: the Folsom Report revisited. Ann Fam Med. 2012;10(3):250-260.
3. Committee on Integrating Primary Care and Public Health of the Board on Population Health and Public Health Practice. Primary Care and Public Health: Exploring Integration to Improve Population Health. Washington, DC: National Academies Press; 2012.

4. Stange KC. Communities of solution. Ann Fam Med. 2012;10(3):iii.

5. Margolis D, Bodenheimer T, Bennett H, Wong J, Ngo V, Padilla G, Thom $\mathrm{DH}$. Health coaching to improve hypertension treatment in a low-income, minority population. Ann Fam Med. 2012;10(3):199-205

6. Kolt GS, Schofield GM, Kerse N, Garrett N, Ashton T, Patel A. Healthy Steps Trial: pedometer-based advice and physical activity for low-active older adults. Ann Fam Med. 2012;10(3):206-212.

7. Usta J, Antoun J, Ambuel B, Khawaja M. Involving the health care system in domestic violence: what women want. Ann Fam Med. 2012;10(3):213-220.

8. Alshamsan R, Lee JT, Majeed A, Netuveli G, Millett C. Effect of a UK pay-for-performance program on ethnic disparities in diabetes outcomes: interrupted time series analysis. Ann Fam Med. 2012;10(3):228-234

9. Rosenfeld RM, Andes D, Bhattacharyya N, et al. Clinical practice guideline: adult sinusitis. Otolaryngol Head Neck Surg. 2007;137 (3 Suppl):S1-31.

10. Hayward G, Heneghan C, Perera R, Thompson M. Intranasal corticosteroids in management of acute sinusitis: a systematic review and meta-analysis. Ann Fam Med. 2012;10(3):241-249.

11. Hickner J. Intranasal steroids for acute sinusitis? Ann Fam Med. 2012;10(3):196-197.

12. Wu J. Rewarding healthy behaviors-pay patients for performance. Ann Fam Med. 2012;10(3):261-263.

13. Christiansen BA. What does it cost to change behavior? Ann Fam Med. 2012;10(3):197-198.

14. Crosson JC, Ohman-Strickland PA, Cohen DJ, Clark EC, Crabtree BF. Typical electronic health record use in primary care practices and the quality of diabetes care. Ann Fam Med. 2012;10(3):221-227.

15. Thompson DM, Fernald DH, Mold JW. Intraclass correlation coefficients typical of cluster-randomized studies: estimates from the Robert Wood Johnson Prescription for Health projects. Ann Fam Med. 2012;10(3):235-240.

16. Ventres W. The joy of family practice. Ann Fam Med. 2012;10(3): 264-268. 